\title{
ORGANIZACIJŲ PASIRENGIMO POKYČIŲ VALDYMUI DEKOMPOZICIJA
}

\author{
Alvydas Raipa \\ Mykolo Romerio universitetas \\ Valakupiu g. 5, LT-10101, Lietuva \\ doi:10.13165/VPA-13-12-4-01
}

Anotacija. Straipsnyje analizuojamas viešuju organizaciju veiklos tobulinimas XXI a. pradžioje yra tiesiogiai sietinas su valdymo kompleksiškumo ịtvirtinimu valstybès instituciniu sistemu funkcionavime. Itin svarbia vieta viešojo valdymo kompleksiškumo struktūroje užima instituciniu, technologiniu ir socialiniu pokyčiu valdymas, reikalaujantis iš viešojo sektoriaus organizaciju pasirengimo keisti tradicines viešojo valdymo vertybes, nusistovejusias tradicijas, veiklos struktūrines-funkcines dimensijas. Globalios aplinkos salygos iš viešojo valdymo instituciju reikalauja radikalios organizaciniu struktūru transformacijos, itin plataus viešojo valdymo lygiu ir rūšiu lauko reformu. Straipsnyje, naudojant kompleksinio požiūrio ì pokyčiu valdyma instrumentines galimybes, taikant metaanalizes, sinektini, teorinio modeliavimo, lyginamosios analizès, klasifikavimo, interpretacinius metodus, siekiama atskleisti strateginio valdymo, organizacinès kultūros, valdymo procesu kaitos modeliavimo lygmens reikšmę viešuju organizaciju pasirengimo pokyčiu valdymui elementams. Autoriaus pastangos yra sufokusuotos $\dot{i}$ viešuju organizaciju veiklos kokybiniu charakteristiku išskyrima. Dominuojantis analizès vektorius yra vidinès ir išorinès organizaciju aplinkos skenavimo bütinumo išskyrimas, siekiant aiškiau identifikuoti veiksnius ir faktorius, nuo kuriu priklauso organizaciju pasirengimo pokyčiu valdymui kokybe, ir determinuojant indikatorius, bütinus vertinant pasirengimo pokyčiu valdymui strategijas, programas, organizaciniu sprendimu lygmeni bei organizaciju pasirengimo pokyčiu valdymui modeliavimo kokybinius parametrus.

Raktažodžiai: viešosios organizacijos, pasirengimas pokyčiams, strateginis valdymas, pokyčiu valdymo modeliavimas, organizacine kultūra.

Keywords: public organizations, preparing to accept change, strategic governance, modeling of changes governance, organizational culture. 


\section{Ivadas}

Šiandieninejje globalioje, sunkiai prognozuojamoje visų rūšių organizacijų valdymo sferoje nebeužtenka tradicinio XX a. antros pusès patyrimo pokyčių valdymo, orientuoto ị inkrementinį valdymo kaitos evoliucionavimą, patyrimo. Politinis, ekonominis-finansinis valstybių nestabilumas chaotiškoje globalių procesų erdveje, išryškèjusios visuomenès socialinès stratifikacijos neigiamos pasekmès reikalauja radikalių pokyčių valdymo proceso transformacijų, naujos organizacinių pokyčių valdymo vizijos suvokimo. Viešojo valdymo pokyčių studijos determinuoja naujų organizacinių procesų ir organizacinių išteklių, ekologinių problemų sprendimų strategijų institucionalizavimo kryptis, formas ir metodus. Organizacijų veiklos arsenale atsiranda institucinès tinklaveikos, tarpsektorinès integracijos, naujos organizacijų socialinès korporatyvinès atsakomybès formos, reikalaujančios iš viešojo sektoriaus organizacijų, jų lyderių žymiai daugiau pastangų, t. y. aukštesnio lygmens pasirengimo pokyčių valdymui parametrų. Todèl šiuolaikinis viešųjų organizacijų pasirengimas pokyčių valdymui reikalauja formuoti naujas metodologines prieigas viešojo valdymo (t. y. ir pokyčių valdymo) teorinėms ir praktinėms problemoms spręsti, rekomenduoti potencialias viešojo valdymo pertvarkos sistemines, struktūrines, procesines pokyčių valdymo dimensijas bei tobulinti tradicinius pokyčių valdymo pokyčius, jų interpretacijas strateginio valdymo organizacinès kultūros kaitos, žinių valdymo, intelektinio kapitalo kūrimo sferose. Itin svarbiais komponentais viešujų organizacijų pasirengimo pokyčių valdymui procese tampa ị rezultatus orientuotos elgsenos įtvirtinimas bendroje organizacinès kultūros erdvèje, valdymo orientacijos tendencijos iš linijinių modelių ị matricines struktūras ir horizontalų valdymą, institucinio žinojimo prioritetų išryškinimą, naujų integracinès sąveikos principų įvaldymą. İvardinti pasirengimo pokyčiams komponentai nèra mechanistiškai suvokiamas priemonių ir instrumentų bei veiklos krypčių rinkinys. Tai itin sudètingas, reikalaujantis iš organizacijų lyderių, vadybininkų naujos organizacinès kultūros kaip naujos vertybių sistemos, inovacinès reformų ideologijos reikšmės suvokimo, gebejimų formuoti pozityvų organizacinį klimatą, telkti organizacinius junginius, tobulinti analitinę-ekspertinę veiklą identifikuojant pasirengimo pokyčiu valdymui problemas, trukdžius ir jų išeliminavimo galimybes.

\section{Šiuolaikinių pokyčių charakteristika ir viešųjų organizacijų uždaviniai}

Visuose Vakarų civilizacijos regionuose valstybė ir viešojo sektorius organizacijos visais laikais išlaikẻ svarbiausias pozicijas teikiant viešąji produktą ir viešąsias paslaugas. Tai buvo užtikrinama vystant viešųjų struktūrų biurokratinị valdymą ir valstybės sistemų funkcionavimo kokybinius parametrus. Modernios šiuolaikinès valstybės kompleksinė plètra nesuvokiama be viešojo sektoriaus ir viešųu paslaugų valdymo sistemų veiklos efektyvumo. Todèl XX-XXI a. sankirtoje valstybės institucijų veiklos profesionalizacijos, tarnautojų kompetencijų vystymas tampa esminiu faktoriumi tobulinant organizacinių 
pokyčių valdymą, keičiantis ir transformuojantis nusistovejusioms administravimo tradicijoms, pasitinkant globalizacijos iššūkius, suponuotus korporatyvinio kapitalizmo vystymosi transnacionalinèje erdvejje, kultūrinès konvergencijos, besiremiančios instrumentinèmis racionalistinių filosofinių koncepcijų argumentacijomis, reikalaujančiomis valdymo reformavimo, organizacinių veiklos procesų reinžinerijos, struktūrinių reformų, viešojo ir privataus sektorių sąveikos dizaino konfigūracijos pokyčių ir esminių kokybinių administracinės-politinès sistemos pokyčiu siekiant aukšto veiklos efektyvumo ir demokratinio valdymo procesų plètros. Tai reikalauja iš viešojo valdymo struktūrų rimto požiūrio ir kompleksinio pasirengimo pokyčiu valdymo procesų visumai [3, p. 127-143].

Šiuolaikinio modernaus viešojo valdymo reformų ideologija ir praktika skirtinguose regionuose priklauso nuo daugelio faktorių: konstitucijų lyderių pasirengimo ir jų gebejjimo sutelkti organizacijų personalą priimant naujas vertybines orientacijas; politikos formuotojų ir administratorių strateginio valdymo gebejjimų išnaudoti naujų, tobulesnių viešojo valdymo formų galimybes. Todèl reikia konstatuoti, kad skirtinguose regionuose pasirengimas pokyčių valdymui iggauna tam tikrus specifinius bruožus globaliame viešojo valdymo reformų kontekste. Naujojo viešojo valdymo specifika pasitinkant pokyčius ir jų suponuotas reformas yra nulemta esminių naujojo viešojo valdymo indikatorių, t. y. kokybiškai naujų ideologinių nuostatų ir valdymo praktikos kaitos viešosios politikos formavime, strateginio valdymo procesuose, tarpsektorinès partnerystės evoliucijoje ị kompleksinę tarpsektorinę integraciją. Pasirengimas visuomenès raidos ir viešojo sektoriaus pokyčiams yra nulemtas ne tik naujosios viešosios vadybos tradicijų išskirtinumų vienoje ar kitoje šalyje, bet ir evoliucijos į naujaji viešaji valdymą dinamiškumo lygmens, jungiančio viešojo valdymo institucinès sąrangos įvairovę, valdžios ir piliečių sąveiką, demokratinio valdymo lygị ir kt. [4, p. 111-119].

Itin svarbiais faktoriais, veikiančiais organizacijų pasirengimą pokyčių valdymui, šiandien tampa viešojo sektoriaus pokyčių, inovatyvių technologijų, veiklos reformavimo ir modernizavimo tyrinètojų pastangos tobulinant šiuolaikinio viešojo valdymo pažinimo analizès galimybes. Teoretikai pateikia gausią teorinio modeliavimo, metaanalizès priemonių rinkinị, kurị galima ịvardinti kaip kompleksinę teorijos vietos viešojo valdymo ideologijoje sampratų, požiūrių ir interpretacijų ịvairovę. Teorijos paskirtis organizacijų pasirengimo viešojo valdymo pokyčiams etape priklauso nuo valstybės viešųjų institucijų strateginių tikslų, uždavinių formavimo kokybinių ir kiekybinių parametrų, t. y. programų specifikos, racionalaus institucijų lyderių personalo mąstymo ir konstruktyvios veiklos.

Svarbiausia teorijos paskirtis organizacijų pasirengimo pokyčiams etape - formuoti mokslinio pažinimo sferos tyrimo (šiuo atveju - viešojo sektoriaus inovacinès aplinkos kūrimo, inovacijų vaidmens vertinimo) metodologinị instrumentarijų, galintị padèti tobulinti sisteminių-procesinių veiklų dedamųjų analizę, išplèsti ekstrapoliacinio modeliavimo galimybes, išvengti strateginès inovacinès praktikos klaidų, išeliminuoti galimus politinius, ekonominius, socialinius trukdžius ir rizikos faktorius [5, p. 3]. 
Organizacijų pasirengimas pokyčių valdymui jungia iššūkius instituciniams, socialiniams ir technologiniams pokyčiams. Technologinių pokyčiu samprata plačiąja prasme yra itin daugiaplanè, apimanti technologines sistemas, sudarytas iš ịvairių lygių subsistemų, susietų technologinių mechanizmų, bei technologinių komponentų. Reikia pažymėti, kad technologiniai komponentai ir subsistemos ne visada yra tame pačiame technologiniame cikle, kaip ir sistemos. Teoretikai dažnai teigia, kad technologiniai pokyčiai organizacijose ir pasirengimas jiems yra tiesiogiai siejamas su antreprenerystės lygmenimis. Technologinių pokyčių lauke šiandien itin išskiriamas interorganizacinis laukas, t. y. tarpsektorinės integracijos, tinklaveikos atitikmuo socialinio proceso pokyčiuose.

Kartu galima teigti, kad socialinių pokyčių modeliavime dažniausiai siekiama išgryninti organizacines pasirengimo pokyčiams problemas, o technologinių pokyčių modeliuotojai determinuoja ne tik pokyčių konstruktus, bet ir jų igyvendintojus, t. y. pokyčių konstravimo ir įgyvendinimo procesus arba visą spektrą institucinès infrastruktūros - inovacines pastangas, antreprenerišką veiklą, e. valdžią, ugdant darbuotojų kompetencijas, technines specializacijas, akumuliuojant bazines žinių, technikos ir gerosios praktikos pasiekimus [17, p. 284-287].

Šiuolaikinio viešojo valdymo technologinių pokyčių spektre greta žinių ekonomikos, aukštujjų technologijų esmine dedamoji yra informacinès technologijos, kurios XXI a. pradžioje vaidina itin svarbų vaidmenị modernizuojant viešąji valdymą ir viešųjų paslaugų teikimo procesų demokratizavimą, įtvirtinat viešumo ir skaidrumo principus e. valdyme. Šiuolaikinė e. plètros samprata jungia informacijos katalogavimą, informacinę sklaidą tiek horizontaliame, tiek vertikaliame lygmenyse. 2008 m. Jungtinių Tautų e. valdymo studijoje parengtas modelis išskiria penkias informacinių technologijų plètros fazes atspindinčius indeksus:

- Apjungiantis,

- Suderinantis,

- Interaktyvus,

- Didinantis,

- Šiuolaikiškai besiformuojantis.

Pirmoje fazèje yra galimybė kaupti informaciją apie organizacijų pasirengimą pokyčiu valdymui. Antroje fazèje informacijos lygis leidžia geriau analizuoti politikos ir administravimo sąveiką. Trečioje fazèje informacijos sklaida ịvairiose organizacijos struktūrų pasirengimo pokyčiams lygmenyse. Ketvirtas informacijos valdymo lygis leidžia sėkmingiau derinti valdžios ir visuomenès sąveiką pasitinkant pokyčius. Penktame lygyje siekiama užtikrinti ịvairių valdymo institucijų valdymo integraciją, t. y. e. valdymo galimybių infrastruktūros funkcionavimą [18, p. 5-7].

Bandant determinuoti šiuolaikinio viešojo valdymo pokyčius, teoretikai naudoja ịvairias jų tipologizavimo galimybes, išskirdami struktūrinius dekompozicinius elementus, apibrèždami pokyčių pobūdị, ypatybes ir kitas charakteristikas, identifikuoti pokyčius 
kaip procesus, jungiančius organizacijų išteklius, ekonomines, socialines, organizacines, kultūrines reikšmes.

Bene dažniausiai pokyčiai mokslinèje valdymo literatūroje tipologizuojami organizacijų valdymo kontekste kaip instituciniai, socialiniai, technologiniai pokyčiai. Organizacijų struktūros, jų veiklos, organizacinès elgsenos bruožai yra esminès dimensijos, išreiškiančios valdymo pokyčių vidinèje ir išorinèje organizacinèje aplinkoje kontekstualumą. Pokyčiai yra objektyvus bendrujų visuomenès egzistencijos procesų padarinys, kadangi organizacijų, individų veiklos vystymosi tendencijos reiškia ịvairias ir skirtingas elgsenos struktūrinès kaitos reikšmes. Pokyčiai reikalauja atsisakyti inertiško požiūrio ir ịtvirtinti inovatyvius siekius keisti nusistovejjusius tradicinius valdymo, veiklos determinantus. Metodologiškai vertingas pokyčiu kaip inovacinio proceso erdvès suvokimas galètų būti išskirtas keliomis esminèmis dimensijomis:

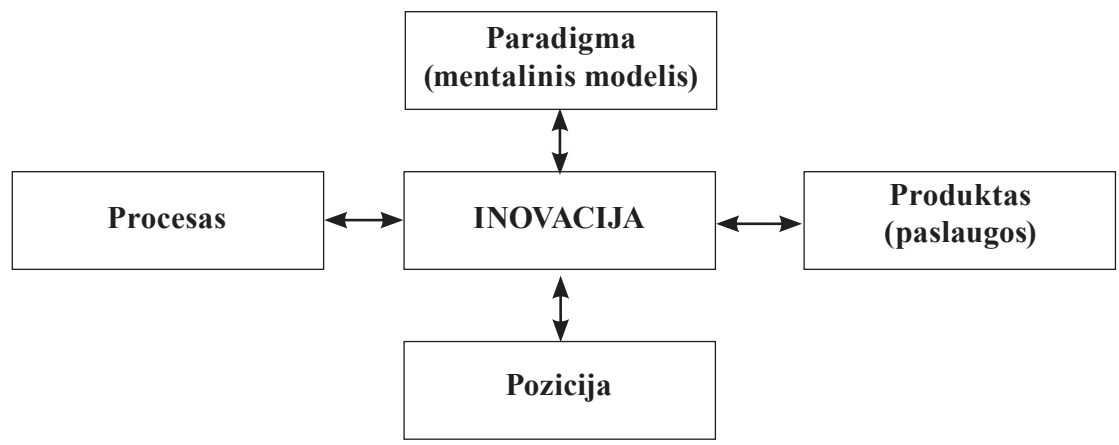

1 pav. Pokyčių proceso erdvès suvokimas

Šaltinis: $[8$, p. 55-56]

- Paradigma - esminių mentalinių organizacijų veiklos modelių pokyčiai;

- Produktas ar paslaugos - organizacijų veiklos rezultatų pokyčiai;

- Pozicija - pokyčių kontekstas, kur paslaugos yra pristatomos;

- Procesas - veiklos proceso pokyčiai teikiant paslaugas.

Praplèsdami organizacinių pokyčių sampratą teoretikai akcentuoja organizacijos veiklos krypčių, tikslų, rezultatų ir perspektyvų trajektorijas, organizacijos sprendimų strateginių krypčių rengimą ir igyvendinimą, išteklių valdymo pokyčių kiekybinius ir kokybinius parametrus, organizacinès elgsenos bei organizacinès kultūros vertybių skales, epizodinị ar permanentinị pokyčių pobūdžius [17, p. 6-7].

Apibendrindami organizacijų pasiruošimą pokyčiu valdymui teoretikai šiandien skiria ir klasifikuoja aplinkos faktorius, veikiančius pokyčių kompleksiškumą globalioje aplinkoje. 
1 lentele. Aplinkos faktoriai, darantys ịtaką globalių pokyčių kompleksiškumui [6, p. 76]

\begin{tabular}{|l|l|}
\hline \multicolumn{1}{|c|}{ Sektorius } & \multicolumn{1}{c|}{ Faktoriai } \\
\hline Technologinis & $\begin{array}{l}\text { Asmeniniai kompiuteriai, internetas ir WIFI, skaitmeninės } \\
\text { kameros ir HDTV, išmanieji telefonai, palydovinis ryšys, greitieji } \\
\text { traukiniai, daugkartinio naudojimo erdvėlaiviai, supertankeriai }\end{array}$ \\
\hline Ekonomikos & $\begin{array}{l}\text { Globali pasaulinė rinka, technologijų pasikeitimas, pasaulinės } \\
\text { prekybos tinklas, transnacionalinės korporacijos, tarptautinės } \\
\text { ekonominės institucijos }\end{array}$ \\
\hline Politinis-teisinis & $\begin{array}{l}\text { Nacionalinės valstybės galių silpnejjimas, teritorinių sienų erozija, } \\
\text { globalaus valdymo institucijų vaidmens augimas }\end{array}$ \\
\hline Socialinis-kultūrinis & $\begin{array}{l}\text { Globali media, populiari kultūra (slengas, mados, prekės ženklai, } \\
\text { muzika), anglų kalba kaip globalios visuomenės kalba (mokslas, } \\
\text { politika, verslas, internetas), materializmas ir vartojimas, } \\
\text { turizmas, multikultūralizmas }\end{array}$ \\
\hline Fizinis & $\begin{array}{l}\text { Gyventojų skaičiaus augimas, atliekų ir industrinės veiklos } \\
\text { pasekmių pavojus, pasauliniai klimato pokyčiai, maisto } \\
\text { aprūpinimo problemos ir nesaugus maistas, genetiškai modifikuoti } \\
\text { produktai }\end{array}$ \\
\hline
\end{tabular}

Analizuodami aplinkos faktorius, turinčius įtakos organizacijų pasirengimui pokyčiu valdymui, teoretikai remiasi pokyčiu kompleksiniu pobūdžiu. Pateikiamame paveiksle analizuojama, kaip generalinè aplinka įsiskverbia ir veikia organizacinių tinklų sistemas pasirengimo pokyčių valdymui procese.

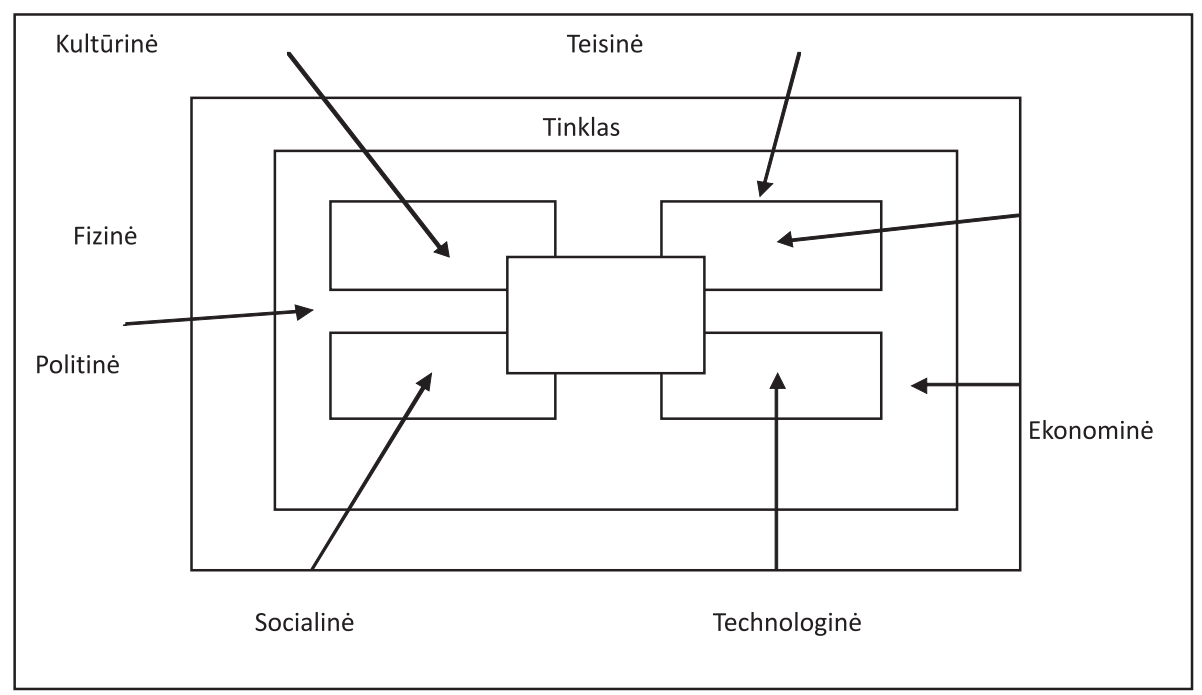

2 pav. Kaip generalinė aplinka ịsiskverbia ị organizacijų ir organizacinių tinklų sistemas Šaltinis: [6, p. 77] 
Sektorių generalinès aplinkos sąlygos, kaip matome, veikia ir ịsiskverbia ị interorganizacinių tinklų sistemas, o organizacijos, kaip organizacijų tinklai, suformuoja naujas aplinkas ir sąlygas bei nustato veikos kryptis.

Organizacijų pasirengimo pokyčiu valdymo procese teoretikai ir praktikai privalo suvokti, kad itin svarbiu faktoriumi tampa sąveika tarp pačios pasirengimo priimti pokyčius politikos ir politikų. Ryšiai tarp šių dimensijų dažniausiai ịvardijami kaip tiesioginiai arba atsitiktiniai, tačiau esmė yra ta, kaip pabrèžia A. Lowi, kad ,politikai determinuoja politiką", tačiau kartu jis argumentuoja, kad politika kaip pasirengimo pokyčiams strategijos, programos ir kt. savo ruožtu determinuoja politikus, t. y. veikia jų pozicijas, pažiūras, riboja arba plètoja jų galimybes, veiklas kaip politikų savirealizacijos formas [21, p. 37].

Suprantant naujojo viešojo valdymo kontekstą, kaip pasirengimo pokyčiams lauko kontekstą, būtina neužmiršti klasikinès politikos-administravimo dichotomijos, kaip doktrinos, išreiškiančios santykinai atskirtų ir tuo pačiu metu glaudžiai sąveikaujančių viešojo valdymo elementų. Šiandieninè politikos ir administravimo dichotomijos samprata dažniausiai ịvardijama kaip valdžios lygių, biurokratinio ir demokratinio valdymo sąveikos forma, kaip tam tikra dilema, kuri gali tiek pozityviai veikti pasirengimą pokyčių valdymui, tiek suponuoti ịvairiausio lygio struktūrinius-sisteminius konfliktus, ardančius konstitucinę sąrangą, įnešančius disharmoniją tarp įvairių valdžių rūšių ir lygių santykių. Antruoju atveju, kai politikos-administravimo dichotomija kaip tipiškas valdžių atskyrimo demokratinis pradas dažniausiai nėra sẻkmingas valstybės sąrangoje, kur yra polinkis ị autoritarinị valdymą, kai tarpinstitucinè integracija dèl subjektyvių ir objektyvių veiksnių nèra užtikrinama, kai tarpsektorinè sąveika ịgauna korumpuotus bruožus, nepotizmo elementus ir kt. Tokiu atveju pasirengimas pokyčių valdymui ir pats procesas yra iš anksto deformuotas pagal formą ir pagal turinị. Tokios situacijos itin būdingos pokomunistinès erdvès valstybinio valdymo šiuolaikinèms trajektorijoms [13, p. 178-181].

Strateginio valdymo tobulinimas organizacijų pasirengimo pokyčiams struktūroje

Organizacijų veiklos praktikoje valdymo pokyčių instaliavimo negalima suprasti kaip greito, momentinio proceso. Pasirengimas pokyčių valdymui - tai greičiau nuolatinès organizacijų pastangos, tikslinga veikla ir racionaliais sprendimais bei šiuolaikine inovacine pokyčių valdymo ideologija paremtas organizacinių strateginių tikslų formavimas ir igyvendinimo galimybių kūrimas, reikalaujantis itin kruopštaus veiklos procesų derinimo, visų organizacijų išteklių mobilizavimo, gebejjimo efektyviai vertinti ir lanksčiai prisitaikyti prie nuolat besikeičiančių globalios visuomenès kaitos tendencijų.

Pasirengimą pokyčių valdymui viešosiose organizacijose šiandien dažniausiai identifikuoja pasirengimo strategijų partnerystès programų ir integracinių projektų kokybinès charakteristikos. Todèl, jas vertinant, galima išskirti daugeli kriterijų:

- Politikos tikslų aiškumas,

- Partnerystès struktūros elementų išryškinimas,

- Projektų sferos, aplinkos suvokimas,

- Rinkos išdèstymo konstrukcija,

- Operatyvinès rizikos veiksnių numatymas,

- Finansiniu galimybių pagrịstumo vaidmuo, 
- Instituciniai ekonominiai pajègumai,

- Investicijų pritraukimo strateginès galimybès [15, p. 365].

Užsienio šalių praktikoje organizacijų pasirengimo pokyčiams strategijoje itin svarbi vieta strategineje vadyboje priklauso programų ir projektų valdymui, kur viena iš svarbiausių dedamųjų yra rizikos valdymas. Tradiciškai rizikos valdymas strateginio valdymo kontekste turi tris fazes:

- Rizikos identifikavimas,

- Rizikos analizè,

- Rizikos vertinimas ir rizikos amortizacija.

Rizikos amortizacija (sušvelninimas) suprantamas kaip rizikos išvengimas, rizikos sumažinimas, rizikos perkèlimas ar transformavimas, žemo rizikos lygmens išlaikymas, todèl šios strateginès kryptys gali suteikti galimybę organizacijų vadovams, vadybininkams geriau prognozuoti, numatyti galimas grèsmes. Kartu rizikos galimybių egzistavimo pripažinimas organizacijų strateginio valdymo kontekste gali sukelti tam tikras abejones, baimes, kontrapreneriškas nuostatas, strateginių programų ir projektų igyvendinimo vertès augimo problemas. Todèl rizikos valdyme, organizacijų strateginiame arsenale itin svarbiais elementais šiandien tampa vadybininkų veiklos lankstumo tobulinimas, esamų išteklių ir galimybių sumanus panaudojimas, t. y. išmintingas rizikos procesų valdymas. Tai galima pateikti grafiškai:

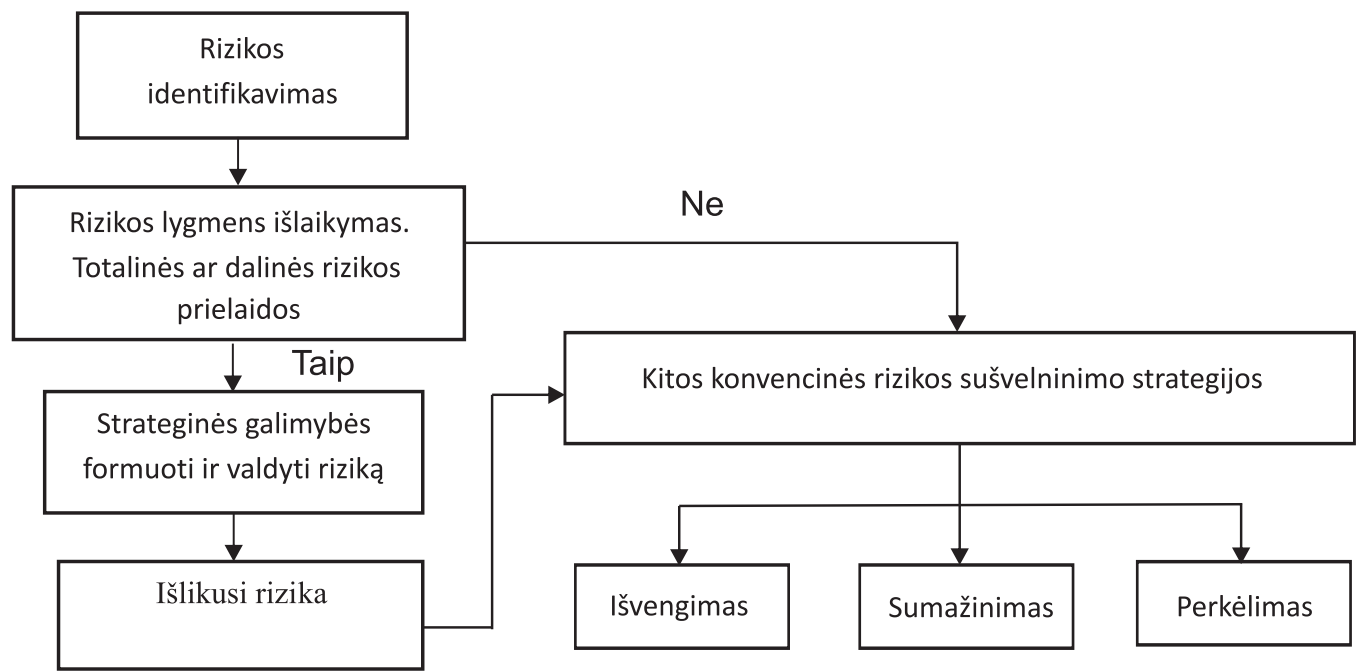

3 pav. Rizikos valdymas infrastruktūriniuose (PPP) projektuose Šaltinis: [15, p. 244]

Organizacijų pasirengimas pokyčių valdymui gali būti sėkmingas ir efektyvus, jei organizacijos pasirengimą koordinuoja organizacijų vadovai, lyderiai, aukščiausio lygmens vadybininkai, galintys užtikrinti organizacijose jų tikslų, misijos, organizacijos vertybių vienovę, išskirti esminius organizacijų poreikius ir prioritetus, aiškiai apibrěžti atsako- 
mybės ir atskaitomybės parametrus bei teisingai koordinuoti efektyvaus igyvendinimo strateginio plano rengimą bei pati ịgyvendinimo procesą. Todẻl efektyvus ir veiksmingas viešojo valdymo organizacijų pasirengimas pokyčiams gali būti užtikrinamas, kai:

- Atsakomybès ribos yra aiškiai apibrèžtos.

- Atskaitomybės metodai organizacijoje yra realiai įtvirtinti.

- İdiegtos tinkamos pasirengimo pokyčiams procedūros, igyvendinant programas ir projektus.

- Užtikrinamas visų rūšių išteklių racionalaus panaudojimo koordinavimas.

- Atsakomybė už pasirengimą pokyčiams yra aiškiai suprasta visose organizacijos grandyse, panaudojant vidines ir išorines komunikacijos galimybes [20, p. 156157].

Organizacijų veikloje pasirengiant pokyčiams itin svarbus yra valdymo ekspertų, kaip aukščiausio lygmens specialistų, įtraukimas ị strateginių prioritetų nustatymo, sprendimų bei programų ir projektų rengimo procesą identifikuojant esamas ar potencialias problemas, organizuojant problemų mokslinès analizès studijas, rengiant interesų grupių, politinių partijų diskusijas. Visa tai yra tam tikras viešojo valdymo tobulinimo pagrindas teisiniais, politiniais ar ekonominiais aspektais, t. y. siekiama pokyčių valdymo procesui suteikti normatyvines, teisines, ekonominio racionalumo dimensijas. Mokslinis požiūris i ekspertų sistemų vietą ir galimybes organizacijų pasirengimo pokyčių valdymui etape leidžia išvengti vadinamos „gaisrų gesinimo“ procedūrinès mišrainès, kartu pasirengimas reformoms, pokyčių valdymui igauna tam tikrą intelektualinị pagrindą, suteikia galimybę pakylèti sprendimų prièmimo kultūrą nuo „parapijinio“ lygmens ị ekspertinị, mokslinių diskusijų ir argumentų pagrindu priimamų sprendimų, alternatyvų analizės ir pasirinkimo lygmeni [19, p. 105-108].

Pasirengimą pokyčiu valdymui organizacijose identifikuoja pasirengimo projektų, partnerystės programų kokybinės dimensijos. Todèl jas vertinant galima išskirti pasirengimo pokyčių valdymui projektų vertinimo kriterijus:

- Politikos tikslų aiškumas.

- Partnerystès struktūra.

- Projektų sfera.

- Aplinkos faktorių aiškumas.

- Rizikos išdèstymo konstrukcija.

- Finansinès galimybės ir ekonominiai pajėgumai bei finansų pritraukimas [15, p. 365].

\section{Organizacinės kultūros vaidmuo pasirengime pokyčių valdymui}

Viena iš esminių žymaus metodologo G. Hofstede'o nuostatų yra idejja, kad organizacijos yra didelès kultūros sistemos subkultūra arba subsistema. E. Sheino organizacinès kultūros teorija remiasi prielaida, kad kultūros proceso aplinkos dalyviai įsitikinę jų adoruojamų kultūros vertybių realybe, kur esminès subkultūros dedamosios yra kultūros prielaidos, kultūros vertybès, kultūrinių vertybių formos ir jų įsitvirtinimas. Normos, vertybès 
ir organizacinė veikla sudaro vadinamąji kultūros artifaktą, išreiškiantị tam tikrą kultūros požiūrị, manifestą, t. y. kultūros esmę, kuri savi ruožtu produkuoja naujas kultūros normas ir vertybes, kurios remiasi esminėmis tradicinėmis kultūros dimensijomis, tačiau kartu atsiranda naujas interpretacinis turinys organizacijų veikloje, garantuojantis naujų bruožų ir vertybių formavimą [6, p. 181-188].

Organizacijų šiuolaikinè charakteristika negalima be naujo požiūrio ị organizacinès etikos standartų, naujos elgsenos ugdymo ir ịtvirtinimo jų veikloje. Organizacijų vadovai ir vadybininkai antrepreneriškoje pokyčių valdymo aplinkoje turi suprasti, kad atsakomybè, skaidrumas ir viešumas nèra tik etiniai imperatyvai, bet ir veiklos kokybės kategorijos. Todèl šiuolaikinių organizacijų lyderiai turi būti pasirengę pokyčiams, siekiant organizacijų veiklos kompleksinio modernizavimo [7, p. 219-220].

XX-XXI a. sandūroje itin išplinta korporatyvinès elgsenos kodeksai ir standartai, kurių iniciatoriais tampa pasaulinès organizacijos. Mūsų nagrinèjamų organizacijų pasirengimui pokyčiu valdymui aspektu svarbiais probleminiais klausimais tampa korporatyvinės organizacijos aplinkos ir socialinės atsakomybės kaip korporatyvinių principų įtvirtinimo lygmens įvertinimas. Todèl pasaulinių organizacijų išgryninti korporatyvinès aplinkos konceptai ir socialinès organizacijų atsakomybės kriterijai, apimantys universalių standartų kūrimą konfliktų ir interesų reguliavimui, korupcijos ir diskriminacijos žmogaus teisių srityje nustatymui, ịsipareigojimų bendruomenei ir visuomenei apskritai realizavimo užtikrinimui yra itin svarbūs organizacinès kultūros elementai. XXI a. pradžioje išaugo atsakomybė už žmogaus teisių režimo ịgyvendinimą, visuotinių šiuolaikinių darbo santykių ir visuomenės darnios plètros strategijų įtvirtinimą. Piliečių korporatyvinė atsakomybė, kaip organizacijos narių veikla, išsiplečia nuo piliečių dalyvavimo toleravimo, t. y. paprasto supratimo apie teisinius valdymo reguliavimo įsipareigojimus ị organizacijų ir individų etinių ir moralinių vertybių skalès išplètimą, finansinių įsipareigojimų ir atsakomybès visuomenei užtikrinimą. Minèti naujos organizacinès kultūros elementai ir jų įtvirtinimas kasdienëje viešųjų struktūrų veikloje yra esminè sąlyga organizacijų sėkmingam pasirengimui pokyčių valdymui užtikrinti [20, p. 21-22].

Pasirengimo pokyčių valdymui procese šiandien itin svarbiu aspektu tampa administracinis kūrybingumas kaip inovacinių pokyčiu valdymo aplinkos faktorius. Organizacinis kūrybingumas jungia organizacijos vadovų ir darbuotojų išmintingumą, pasitikejjimą, imlumą naujovėms, gebejjimą keistis. Kartais tokios viešojo sektoriaus darbuotojų savybès nèra aktyviai išreikštos ypač pasirengimo pokyčių valdymui etape, kai organizacijų aplinka yra nepakankamai antrepreneriška. Todèl kartais galima susidaryti ịspūdị apie organizacijų, struktūrų, jų darbuotojų nepakankamą imlumą, gebejimą mokytis ir keistis. Tačiau dar 1949 m. žymus valdymo tyrinètojas J. Dewey teigè, kad nepakankamai išreikštas imlumas nereiškia organizacijos ar individo tiesioginio pasyvumo. Jis teige, kad reikalingi tam tikri faktoriai, priartinantys pasyvumo fazès pabaigą ir perèjimą i organizacinès veiklos aktyvumo (pokyčių, modernizavimo, reformų, transformacijų) fazę. Tačiau tai būtų tik mechanistinis perejimo iš vienos organizacinès kultūros fazès ị kitą suvokimas, jei nesuvoktume, kad ir pasyvumo fazèje, t. y. organizacinèje terpèje, nebręstų ir nebūtų brandinamos pokyčių užuomazgos, t. y. inovatyvios ideologijos, naujų technologinių 
galimybių įsisavinimo pasirengimas, darbuotojų lavinimo būtinumo ir žinių visuomenès kūrimo suvokimas. Todèl nemažai pasyvios organizacinès aplinkos ir veiklos fazès elementų yra pozityviai vertinami ir dažnai „perkeliami“ organizacijai transformuojantis ị kūrybingos (aktyviai pokyčius valdančios, diegiančios inovacijas) organizacinès veiklos fazę [11, p. 8-11].

Naujos organizacinès kultūros, administracinio kultūringumo ugdymas tiesiogiai siejamas su besimokančios organizacijos paradigma, kuri gali būti suvokiama analizuojant tris esmines dimensijas: socialinę, struktūrinę ir technologinę, kurių vienovẻ stimuliuoja veiklos optimizavimą šiuolaikinèje organizacinių pokyčių būsenoje. Socialinès dimensijos dedamosios yra lyderystė, viešasis dalyvavimas, strateginio valdymo reinžinerija, organizacijos darbuotojų teisių valdyme išplètimas. Struktūrinė dimensija suteikia valdymo procesams horizontalios integracijos - tinklų plètrą ir organizacinių struktūrų sąrangos kaitą. Technologinè dimensija reiškia technologijų panaudojimą ir galimybę konkretizuoti organizacijų prisitaikymą ir pasirengimą pokyčiams. Besimokančios organizacijos, kaip naujos organizacinès kultūros siekiančios struktūros, naudoja šias tris dimensijas tobulindamos valdymo kontrolę nuolat kintančioje aplinkoje, daugiausia dėmesio skirdamos žinių, informacijos valdymui, intelektinio organizacijų kapitalo formavimui, informacijos sklaidos plètojimui [2, p. 30-42].

Besimokančios organizacijos paradigma pasiruošimo pokyčių valdymui kontekste neatsiejama nuo žinių ekonomikos, žinių valdymo ir informacinès visuomenès kūrimo. Žiniomis grịstos organizacijos veikla XXI a. tiesiogiai siejama su inovacinių idejų paieška, inovatyvumo plètra, mokslinių tyrimų taikymu viešųjų organizacijų veikloje. Rinkos ekonomikos sąlygomis tai įmanoma ne tik skatinant investicijas, bet ir komercializuojant mokslinių tyrimų sferą. Mokslo komercializacija kaip patentiné veikla, smulkaus verslo inovacijų plètra, licencijavimo pokyčiai šiandien plètoja žinių gamybos funkcionalumą, kūrybingą institucinę aplinką. Visa tai naujojo viešojo valdymo sąlygomis, kur vienas iš esminių indikatorių yra tarpsektorinè integracija ir ịvairios tinklaveikos formos, yra itin svarbu tobulinant organizacijų pasirengimą globaliems pokyčiams, jų suponuotoms reformoms, inovacijų diegimo valdymui [1, p. 176-187].

Organizacijų pasirengimo pokyčių valdymui etape dominuojanti viešojo valdymo dedamoji yra viešoji politika, kaip esminis fundamentas formuojant pokyčių valdymo strategijas, programas, rengiant projektus bei būsimus sprendimus. Todèl itin reikšmingą vietą visuminejje tinklaveikos struktūroje užima politikos tinklai, XXI a. pradžioje igaunantys „antrajij“ kvėpavimą ir ženkliai veikiantys tarpsektorinès integracijos, viešojo valdymo tinklaveikos kontekstą, kaip strateginių, analitinių viešųjų struktūrų, valdymo subjektų pastangų ir veiklos galimybių visumą. Tokie žinomi politikos tinklų modeliai, kaip „geležinio trikampio“, „problemų tinklü“, „politikos bendruomenių“, „politikos preferencijų gynimo" ir kiti, moderniose organizacijose yra natūralios valdymo priemonès organizaciju pasirengimo pokyčių valdymui kontekste [10, p. 17-26]. 


\section{Viešųjų organizacijų pasirengimo pokyčių valdymui modeliavimas}

Organizacijų pasirengimo pokyčiams kokybė priklauso nuo analitinių organizacijų pastangų, mišrios analitinès sintezès (kaip problemų identifikavimo, problemų filtravimo, prognozavimo, galimybių analizès, vertinimo, stebėsenos metodų ir procedūrų visumos) metodologijos teikiamų galimybių ịvaldymo, nustatant realias organizacijos pokyčių kryptis ir identifikuojant esamą organizacijos potencialą, modeliuojant pokyčių strategines kryptis ir jų iggyvendinimo mechanizmus. Tai reikalauja iš viešųjų struktūrų užtikrinti būtiną ryšį tarp analizès ir pokyčių valdymo planavimo, pokyčių valdymo programinių nuostatų ịtvirtinimo, organizacinès elgsenos transformavimo ị naujojo viešojo valdymo doktrinos organizacinès elgsenos dimensijas atitinkančią organizacinę kultūrą.

Modeliuojant organizacijų pasirengimą pokyčiu valdymui būtina identifikuoti pasirengimo pokyčių valdymui proceso elementus, jų tinkamumą ir sąveiką. Tai reikalauja iš organizacijos vadovų, ekspertų sisteminès pasirengimo procesų kokybės analizės. Tokie organizacijų pasirengimą pokyčių valdymui analizuojantys tyrimai, vertinimas reikalauja kūrybiškumo, ižvalgumo, netgi tam tikros intuicijos. Todèl organizacijose atliekami tyrimai, savianalizè, vertinimai leidžia geriau suprasti pokyčių valdymo esmines sąlygas, faktorius, išskirti komunikavimo vaidmenị. Tai ir yra organizacijų pasirengimo pokyčių valdymui sèkmès esminès prielaidos.

Organizacijų pasirengimo pokyčiu valdymui procese būtina identifikuoti pokyčių valdymo varomąsias jègas, t. y. atlikti vidinès ir išorinès pokyčių valdymo aplinkos veiksnių, faktorių, priemonių ir kitų dedamųjų determinavimą.

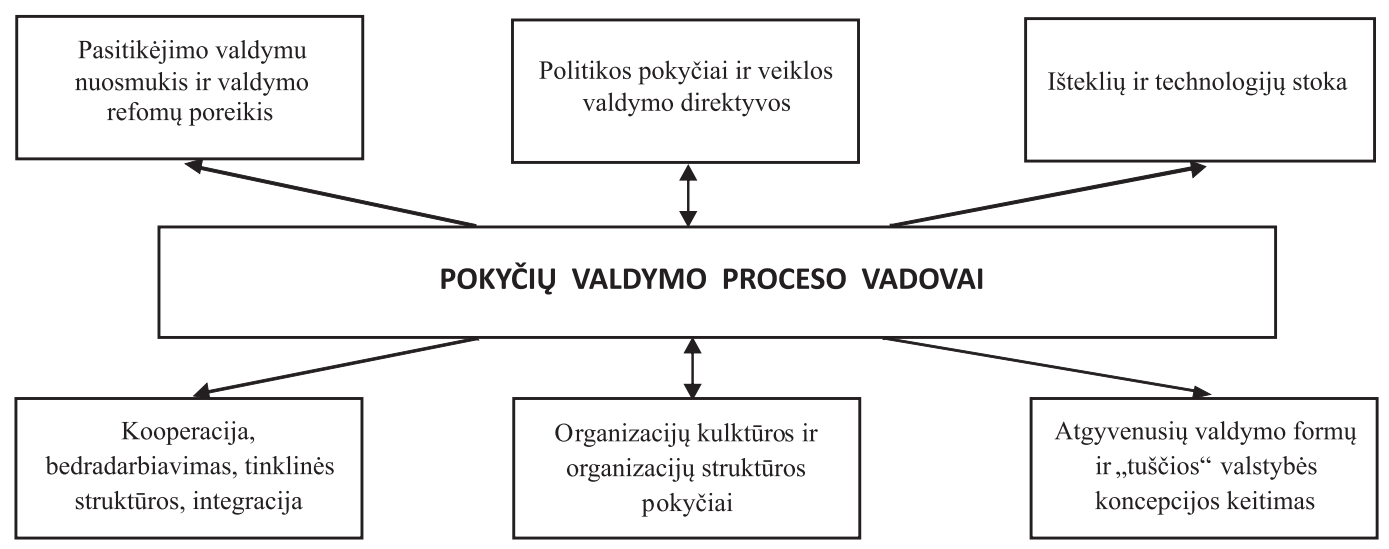

4 pav. Pokyčių valdymo proceso aplinkos varomosios jègos

Šaltinis: [9, p. 35]

Pasirengimas pokyčių valdymo analizei iš organizacijų vadovų, vadybininkų, viešųjų institucijų steigèjų reikalauja tam tikros sekos. Tokia organizacijų pasirengimo pokyčių valdymui modeliavimo seka apima daugeli etapų: 
1. Idejjas, kaip žinių, tikejjimų, vizijų apie pokyčius visumą.

2. Gilesnès sąveikos paieškas, ị analitinị modeliavimą įtraukiant esamas teorijas, konceptus, jau patikrintus pokyčių valdymo modelius. Didžiausia vertybe tampa kritinis požiūris debatuose, diskusijose.

3. Esamų egzistuojančių žinių, modelių analizę, galimybę taikyti analogų (sinektinị) metodą, esamų dokumentų, šaltinių, antrinių duomenų analizès atvejus, taip prognozuojant galimą organizacijų pasirengimo pokyčiams modelį.

4. Organizacijos modelio parengimą, pilotinį testavimą, modelio struktūros reinventorizavimą ir galutinị pritaikymą specifinèms organizacijos reikmėms [12, p. 7-13].

Pokyčių valdymui gali būti tinkamai pasirengta, jei organizacijų vadovai geba atlikti daugybę pasirengimo užduočių ne kaip atskirų, vienas nuo kito mažai priklausomų veiksmų, bet užtikrinti kompleksinị veiklos pobūdị. Ch. Pollitt išskiria kompleksinio požiūrio įvaldymo konceptualius elementus, nuo kuriu priklauso visa apimanti organizacijų pasirengimo pokyčiams erdve, faktoriai, indikatoriai ir kt.:

1. Laiko (trukmės) konceptas. Paprastai tai reiškia, kokie terminai reikalingi organizacijos pasirengimui pokyčiu valdymo, veiklos procesų reformoms, inovatyvios ideologijos îtvirtinimui organizacijos kultūroje.

2. Krypties (kelio trajektorijos) konceptas, kuris grindžiamas esmine idèja apie pasirinktos krypties rezultatų, galimybių tendencijų potencialumą.

3. „Galimybių lango“ konceptas. Jis reikalauja protingos antrepreneriškos veiklos, kai reikia radikaliai keisti sprendimus, susijusius su staigiais pokyčiais, keičiančiais organizacijų veiklos pobūdị ir kryptị. Tokie pokyčiai gali būti iš anksto prognozuojami, numatomi, jiems rengiamasi iš anksto, kompleksiškai išnaudojant ,galimybių langą“ pokyčių instaliavimo sprendimams priimti.

4. Ciklų konceptas, reiškiantis, kad pasirengimas pokyčiams gali (ir turi būti) gerai struktūruotas, evoliucinis procesas, kiekviename cikle sprendžiantis tam tikrus organizacijų pasirengimo pokyčiams socialinius, ekonominius, finansinius uždavinius.

5. Priežastingumo mechanizmo konceptas, igalinantis detaliai paaiškinti ịvairias aplinkybes, kodèl tam tikri procesai, įvykiai, veiksmai susiklosto, atsiranda, formuojasi ar išnyksta bendrame aplinkybių kontekste.

6. Mišrus laiko konceptas, kuris yra tam tikras metakonceptas, apimantis anksčiau pateiktus konceptualius kompleksinio pažinimo elementus, t. y. pripažistama objektyvūs ir subjektyvūs veiksniai, jų poveikis, cikliškumas, laiko faktorius konstruojant organizacijos pasirengimo pokyčiams struktūrą, numatant perspektyvias veiklos kryptis [16, p. 143-145].

Pokyčiu valdymo pasirengimui šiandien pakankamai tinkamu galima laikyti J. Q. Wilsono išskirtą keturių politikos rengimo stilių modelį, kuris remiasi kaštų ir pajamų analizès metodologinių sampratų ịvairove. 
2 lentelè. Politikos rengimo stilių modelis [19, p. 109]

\begin{tabular}{|l|l|l|}
\hline $\begin{array}{l}\text { Eil. } \\
\text { Nr. }\end{array}$ & \multicolumn{1}{|c|}{ Stiliaus pavadinimas } & \multicolumn{1}{c|}{ Būdingi stiliaus požymiai } \\
\hline 1. & Mažoritarinés politikos & $\begin{array}{l}\text { Charakterizuoja problemas, susijusias su kaštų ir pajamų } \\
\text { distribuciniais mechanizmais }\end{array}$ \\
\hline 2. & Klientų politikos & $\begin{array}{l}\text { Charakterizuojamos problemos, susijusios su kaštų } \\
\text { distribucija ir pajamų koncentracija }\end{array}$ \\
\hline 3. & $\begin{array}{l}\text { Antrapreneriškos } \\
\text { politikos }\end{array}$ & $\begin{array}{l}\text { Charakterizuojamos politikos, susijusios su kaštų } \\
\text { koncentracija ir pajamų distribucija }\end{array}$ \\
\hline 4. & Interesų grupių politikos & $\begin{array}{l}\text { Charakterizuojamos problemos, susijusios su kaštų ir } \\
\text { pajamų koncentracija }\end{array}$ \\
\hline
\end{tabular}

Dar XX a. pabaigoje teoretikai „išgrynino“ vadinamajji „nereguliuojamo valdymo“ modeli, kuris tapo viena iš kertinių naujosios viešosios vadybos metodologinių konstrukcijų. Šio modelio principinès nuostatos skelbè, kad viešojo valdymo struktūrų nepasirengimą, nefunkcionalumą, organizacijų veiklos disfunkcijas dažnai lemia organizacijų vadovų, lyderių nekompetencija organizuojant institucijų veiklą valdant išteklius, užtikrinant tarporganizacinę sąveiką, vidinius struktūros ryšius, rengiant organizacijos strategines užduotis, nustatant prioritetus, veiklos taisykles, t. y. identifikuojant svarbiausius organizacinės veiklos standartus, tarp jų ir pasirengimą pokyčių valdymui. Toks kompleksinis organizacinès aplinkos vertinimo modeliavimas gali būti itin svarbus analizuojant tiek pasirengimo pokyčiu valdymui trukdžius, tiek institucinès rizikos bendrąsias formas, tiek inovatyvumo plètrą. Antra vertus, modelio hipertrofuotas vertinimas ir pernelyg didelis susižavejimas jo galimybėmis teikiant viešąsias paslaugas išimtinai pagal rinkos modelio konstrukcijas, suponavo naujosios viešosios vadybos schematišką, kartais dogmatišką taikymą, kas neišvengiamai vedè prie disfunkcinių padarinių ir veiksnių tarpsektorinio bendradarbiavimo valdymo demokratizavimo sferose [14, p. 345-346].

\section{Išvados}

1. Šiuolaikinis viešojo valdymo etapas yra determinuotas globalių pokyčių, reikalaujančių radikalių politinių, socialinių, ekonominių reformų. Jų ịgyvendinimas moderniose valstybėse vyksta keičiantis ir transformuojantis tradicinėms viešojo valdymo vertybėms, taikant sisteminį-struktūrinį metodą turint esminį tikslą modernizuoti valdymą, būtiną siekiant valdymo efektyvumo ir veiksmingumo, aukštesnio viešojo valdymo procesų demokratizavimo lygmens. Viešojo valdymo pokyčiai reikalauja iš valstybės institucijų sisteminio kompleksinio pasirengimo pokyčių valdymui, kuris įvairiuose regionuose ir valstybėse greta universalių elementų turi ir specifinius bruožus. Tai pasakytina ir apie pasirengimo pokyčių valdymui struktūrą, kurios elementai, tokie kaip strateginių krypčių 
projektavimas, analitinės-ekspertinès veiklos lygmuo, organizacinės kultūros struktūra bei gebejimai modeliuoti ir įdiegti patikrintus pokyčių valdymo modelius, šalyse yra gana skirtingi.

2. Pasirengimo pokyčių valdymui struktūroje išskirtinę vietą užima strateginio valdymo metodologijų taikymas. Itin svarbiais akcentais tampa strateginių organizacijos tikslų ir priemonių pasirengiant pokyčių valdymui numatymas, gebẻjimas panaudoti Vakarų šalių patirtị, geriausią viešojo sektoriaus praktiką formuojant organizacijų strateginius tikslus ir uždavinius, identifikuojant rizikos faktorius, skenuojant vidines ir išorines organizacijų galimybes, mobilizuojant organizacinius visų rūšių išteklius. Svarbiausia organizacijos pasirengimo pokyčių valdymui potencialo dedamąja tampa subjektyvus faktorius, t. y. organizacijų vadovų ir personalo, ekspertų pastangos, gebejjimai, motyvaciniai elementai, igalinantys pozityviai veikti pasirengimo pokyčių valdymui procesų kokybinius parametrus.

3. Praktikuojant pasirengimą pokyčių valdymui kaip bendros organizacinès veiklos dalį, itin svarbi dedamoji yra organizacinès kultūros, kaip vertybių, tradicijų, veiklos standartų pokyčių, atnešančių naują turinį ir naujas formas ir ị vadybinę veiklą, vaidmuo. Išskirtinis teoretiku dėmesys šiandien skirtas viešųju organizacijų korporatyvinès elgsenos standartų ir kodeksų teoriniam pagrindimui. Šioje veikloje rimtą postūmį dažnai suteikia pasaulinės organizacijos, turinčios ịvairių regionų korporatyvinès organizacijų aplinkos kūrimo ir socialinès korporatyvinès organizacijų atsakomybės ugdymo vertinimo, lyginamosios analizès patirtị ir universalių standartų bei kriterijų rekomendavimo galimybes.

4. Modeliuojant viešųjų organizacijų pasirengimą pokyčių valdymui išskirtinis vaidmuo tenka organizacijos valdymo kokybinèms dimensijoms, kaip tam tikrai indikatorių visumai, iš kurios galima spręsti, kiek organizacijos potencialas leidžia kokybiškai atlikti problemų, susijusių su pasirengimo pokyčių valdymo proceso modeliavimui, t. y. kokio lygmens organizacijos analitinis potencialas, kiek ir kokio lygmens ekspertų sistemų ir ekspertizių būtina siekiant tinkamai pasirengti pokyčių valdymui. Itin svarbu analitinès veiklos procese identifikuoti pokyčių valdymo strategines, programines kryptis, pačią pasirengimo pokyčių valdymui struktūrą suvokti kaip tam tikrą veiklos valdymo proceso struktūrinių elementų seką, t. y. modelį, kaip dirbtinès realybės rekonstrukciją, susidedančią iš daugelio žingsnių, kurių kiekvienas turi savo faktorius, indikatorius, stilius ir kitas matavimo bei vertinimo dimensijas.

\section{Literatūra}

1. Acs, Z., Andretsch, D., Strom, R. Entrepreneurship, Growth and Public Policy. Cambridge: University Press, 2009.

2. Brown, H., Brudney, J. Learning Organizations in the Public Sector? A Study of Police Agencies Emploing Information and Technology to Advance Knowledge. Public Administration Review, 2003, 63 (1), 30-42. 
3. Farazmand, A. Administrative Ethics and Professional Competence. International Review ofAdministrative Sciences, 2002, 68(1), 127-143.

4. Lynn, L. Endures? Public Governance and the Cycle of Reform. - The New Public Governance. Ed. St. Osborne. London: Routledge, 2010.

5. Fredericson, G. The Public Administration Theory Primer. Pitsburg: Westview Press, 2003.

6. Hatch, J., Cunliffe, A. Organization Theory. Oxford: University Press, 2006.

7. Herington, J. Players in the Public Policy Process. New York: Palgrave Mc Millan, 2005.

8. Isaksen, S., Tidd, J. Meeting the Innovation Challenge: Leadership for Transformation and Growth. Chichester: John Willey \& Soons, 2006.

9. McNabb, D. The New Face of Government. New York: CRC Press, 2009.

10. Mikkelsen, M. Policy Network Analysis as a Strategic Tool for the Voluntary Sector. Policy Studies, 27(1), 17-26.

11. Ortega, K., Eizaquire, A., Wenca, M. Can Leisure Studies Enlighten the Development of Cultural Audiences? Journal of Cultural Management and Policy, 2012, 2(2), 8-11.

12. O Sullivan, E., Rassel, G., Berner, M. Research Methods for Public Administration. New York: Longman Publishers, 2010.

13. Overem, P. The Politics - Administration Dichotomy. New York: CRC Press, 2012.

14. Peters, B. Guy. Biurokratijos politika. Vilnius: Algarvè, 2003.

15. Policy, Finance, \& Management for Public - Private Partnership. Ed. Akintoje, A., Beck, M. Oxford: Blackwell Publishers, 2009.

16. Pollitt, Ch. Time, Policy, Management. Oxford: University Press, 2008.

17. Poole, M., Van de Ven, A. Handbook of Organizational Change and Innovation. Oxford: University Press, 2004.

18. Reddick, Ch. Comparative E- Government. Heidelberg: Springer, 2010.

19. Rich, A. Think Tanks, Public Policy and the Politc of Expertise. Cambridge: University Press, 2004.

20. Silverman, M. Compliance Management for Public, Private, or Nonprofit Organizations. New York: Mc Graw - Hill, 2008.

21. Smith, K., Larimer, Ch. The Public Policy Theory Primer. New York: Westview Press, 2009.

Alvydas Raipa

\section{Decomposition of Preparing Public Organization for Governance Change}

Abstract

The purpose of this article is to analyse theoretical-methodological aspects of preparing public organization for the implementation of transformational changes and improvement of organizational performance, establishing the preparing complexity in organization strategy directions. The process of preparing public organization for accepting a change includes many elements: analysis of internal and external environment, identification of different theoretic attitudes for improving organizational performance methodology, typology of changes and best modern governance practice cases.

The main tasks of the study are to accentuate the impact features of global changes to public sector organization development and to identify the role of organizational culture and successful leadership ensuring the implementation of strategy tasks. The essential ingredients of preparing public organization to accept a change are the following: quality of global change analysis, 
identification of the need for modernization, reform and innovation, creation capabilities to improve performance management in all kinds and levels of governance structures. Additionally, preparing to accept a change requires development of new forms and levels of organizational leadership regulatory responsibilities, creation of new governance strategies and implementation of modern control methods. Public sector organizations in achieving the goals use network based strategies as a modern sophisticated form of strategic governance.

The article describes preparing public organization to accept the change partly as the product of innovation installing in public governance. To understand the change typology and decomposition and its role in public governance modernization, from staff and all level organization managers requires to improve administration creativity, getting the abilities to install radical changes, avoiding risk and preparing new models for recovering change governance process.

Alvydas Raipa - Mykolo Romerio universiteto Politikos ir vadybos Fakulteto Viešojo administravimo instituto profesorius, socialinių mokslų daktaras.

E. paštas: alvydasraipa@mruni.eu

Alvydas Raipa, Dr. habil. of Social Sciences, Mykolas Romeris University, Faculty of Social Sciences, Institute of Public Administration, Professor.

E-mail: alvydasraipa@mruni.eu

Straipsnis ịteiktas redakcijai 2013 m. rugsèjo $21 \mathrm{~d}$; recenzuotas; parengtas spaudai $2013 \mathrm{~m}$. spalio mèn. 